
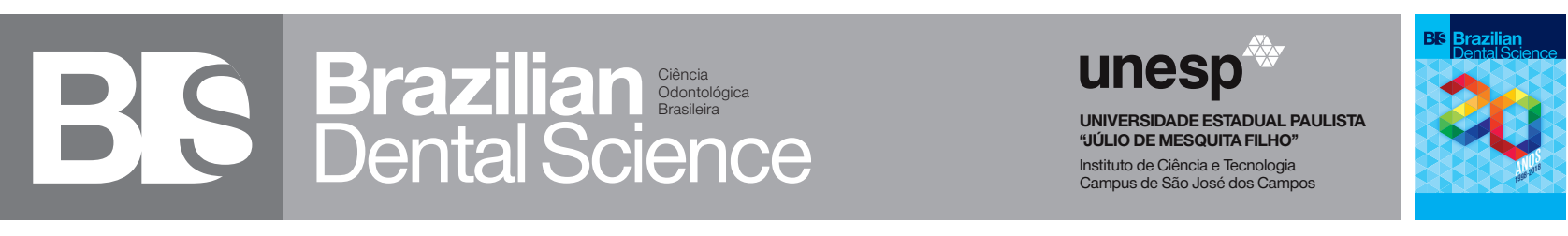

\title{
Effect of the irrigation protocols on the elimination of dentin debris from simulated lateral canals
}

Efeito do método de irrigação na eliminação de debris dentinários em canais late-rais simulados

Pedro Cesar Gomes TITATO ${ }^{1}$, Lyz Cristina Furquim CANALI ${ }^{1}$, Jussaro Alves DUQUE ${ }^{1}$, Rodrigo Ricci VIVAN ${ }^{1}$, Marco Antonio Hungaro DUARTE $^{1}$

1 - Bauru School of Dentistry - University of São Paulo - Operative Dentistry, En-dodontics and Dental Materials - Bauru - SP - Brazil.

\begin{abstract}
Objective: Computed microtomography was used to evaluate the capacity of debris removal from simulated lateral canals, in conventional irrigation, passive ultrasonic irrigation (PUI), continuous passive irrigation (CUI), Endoactivator and EasyClean, for both types of motion (continuous and reciprocating). Material and Methods: Sixty acrylic incisors with 3 simulated lateral canals per tooth (cervical, middle and apical third) were instrumented with Reciproc 40/06 and then filled with dentin debris. The teeth were scanned and divided into 6 groups $(\mathrm{n}=10)$ according to the irrigation protocol: G1 - conventional, G2 - PUI, G3 CUI, G4 - Endoactivator, G5 - EasyClean continuous rotation and G6 - EasyClean reciprocating. After the irrigation protocols, the samples were scanned again. The initial and final volume images were analyzed and the percentage of debris removal were found for each group in all levels. Results: There were significant differences between the initial and final volume of debris after the protocols, with the exception of conventional irrigation group in the apical and cervical thirds, EasyClean reciprocating in the middle and cervical thirds, and CUI in the middle third. In the analysis between the groups: in the apical third, Endoactivator and PUI removed more debris than CUI $(\mathrm{p}<0.05)$; in the middle and cervical thirds, PUI was more efficient than conventional irrigation, EasyClean reciprocating and CUI $(p<0.05)$. Conclusion: No method completely removed the debris. PUI was the method that showed greater effectiveness in cleaning the lateral canals.
\end{abstract}

\section{KEYWORDS}

Root canal therapy; Microct; Dentin; Ultrasonic therapy.

\section{RESUMO}

Objetivo: O objetivo desse estudo foi avaliar a capacidade de remoção de debris de canais laterais simulados através da microtografia computadorizada (microCT), na irrigação convencional, ultrassônica passiva (IUP), ultrassônica contínua (IUC), Endoactivator e EasyClean, para os dois tipos de movimento (contínuo ou alternado). Material e Métodos: Sessenta incisivos de acrílico com três canais late-rais simulados por dente (terço cervical, médio e apical) foram instrumentados com Reciproc 40/06 e preenchidos com debris de dentina bovina. Os dentes fo-ram escaneados e divididos em 6 grupos ( $n=10):$ G1 - convencional, G2 - IUP, G3 - IUC, G4 - Endoactivator, G5 - EasyClean rotação continua e G6 - EasyClean reciprocante. Depois do protocolo de irrigação, as amostras foram novamente escaneadas. $O$ volume inicial e final das imagens foram analisados e o percentual de debris removidos foram encontrados para cada grupo nos três terços. Resultados: Todos os grupos obtiveram diferenças significantes após o proto-colo de irrigação, com exceção do grupo da irrigação convencional nos terços apical e cervical, EasyClean reciprocante (médio e cervical) e IUC no terço médio. $\mathrm{Na}$ análise intragrupo para o terço apical, EndoActivator e IUP removeram mais debris que IUC $(p<0,05)$; no médio e cervical, IUP foi mais eficiente que a irrigação convencional, EasyClean reciprocante e IUC $(\mathrm{p}<0,05)$. Conclusão: Nenhum método foi capaz de remover completamente os debris. A irrigação ultrassônica passiva foi a que demonstrou melhor efetividade na limpeza dos canais laterais.

\section{PALAVRAS-CHAVE}

Tratamento do canal radicular; Microtomografia por raio-X; Terapia por ultras-som; Dentina. 


\section{INTRODUCTION}

$\mathrm{R}$ emoval of all the vital or necrotic tissue, smear layer and dentin debris, in addition to infection control are fundamental conditions for a successful endodontic treatment [1]. These conditions become more difficult to achieve in the case of teeth that presents ramifications, lateral canals and isthmus [2-4].

In these regions of complex anatomy, microorganisms and debris produced by the shaping procedure can accumulate [5]. The mechanical action of instruments fails to reach these areas, making it even more difficult to clean the root canal system [6-8]. This is why instrumentation has to be associated with irrigation pro-tocols that can reach these complex anatomical areas and efficiently clean them.

However, studies shows that conventional irrigation with syringe and needle tips has limitations, especially in areas of difficult access $[2,5,8,9]$. Furthermore, the maintenance of tissue and dentin debris is known to be capable of harboring in-fection, occupying space and even damaging adequate sealing of the root canal system [10].

Sonic, ultrasonic and mechanical methods have been used to optimize cleaning of the root canal system, increasing the effectiveness of irrigation [2,3,5,11].

A widely used and researched sonic method is the Endoactivator (Dentsply, Maillefer, Ballaigues, Switzerland), composed of a handpiece to which polymer tips are attached. These are inserted into the root canal 1 or $2 \mathrm{~mm}$ from the work-ing length for agitating the irrigating solution $[12,13]$.

Two ways of using ultrasonic irrigation have been proposed: Passive Ultrasonic Irrigation (PUI) and Continuous Ultrasonic Irrigation (CUI). In PUI, the liquid is in- troduced into the root canal with a syringe; then a specific ultrasonic device is in-serted into the canal 1 to $2 \mathrm{~mm}$ from the working length and the irrigation solution is activated [14-16]. In CUI, however, there is a needle attached to the ultrasonic device, promoting simultaneous irrigation and activation of the solution, enabling the irrigant to be replaced continually.

A mechanical method recently developed by Easy Company (Easy Dental Equipment, Belo Horizonte, MG, Brazil) is the Easy Clean instrument. This tip can be used coupled to a continuously rotating contra-angle or to a reciprocating mo-tor $[16,17]$. However, there is still a shortage of studies showing the efficiency and ability of this to clean and remove debris from lateral canals.

Therefore, this study aimed to verify, by means of volumetric analysis using micro-computed tomography (microCT), the ability of conventional irrigation, PUI, CUI, Endoactivator and Easy Clean in both types of motion (Continuous and re-ciprocating), to remove dentin debris from simulated lateral canals. The null hy-pothesis was that there would be no difference among irrigation methods in their ability to remove debris from simulated lateral canals.

\section{MATERIAL AND METHODS}

\section{Preparation of the samples}

Sixty acrylic maxillary incisors with simulated lateral canals standardized were used (Figure 1A). The canal diameter corresponded to the size of a $\mathrm{K \#} 8$ file (Dentsply-Maillefer, Ballaigues, Switzerland), and canals were located in the proximal region in the cervical, middle and apical thirds, with a total of 3 lateral canals per tooth. Coronal opening and initial canal exploration were performed with a K\#10 file (DentsplyMaillefer, Ballaigues, Switzerland) and the working length was determined. Subsequently, 
the canals were instrumented with the Reciproc 40/06 endodontic instrument (VDW, Munich, Germany), coupled to a VDW Silver motor (VDW, Munich, Germany), in the Reciproc function, with crown-apex preparation and in/out movements. During instrumentation, irrigation with a total of 6 $\mathrm{mL}$ of distilled water was performed with a 30 gauge navitip needle (Ultradent, Utah, USA) coupled to a disposable syringe. After the instrumentation, they were inserted into a metal muffle containing silicone and removed after the silicone had set. Then the teeth were sectioned in buccolingual direction (Figure 1B) and the lateral canals were filled with bovine dentin debris (Figure 1C). The-se debris were simulated through the wear of extracted bovine teeth, approved by the Ethics and Research Committee on Animals with registration number: 001/2017 - CEEPA/FOB/USP, using a spherical drill steel No. 6 (KG Sorensen, Cotia, SP, Brazil) and was mixed with sodium hypochlorite at a concentration of $2.5 \%$ and compressed into the lateral canals. The teeth were initially scanned by computed microtomography (SkyScan 1174; SkyScan, Aartselaar, Belgium) with parameters of $9.47 \mu \mathrm{m}$ voxel size, $50 \mathrm{kV}, 800 \mathrm{~mA}, 0.8$ size rotation and $1024 \times 1304$ resolution.

\section{Irrigation protocols}

After the initial scanning, specimens were reassembled in a muffle with silicone and divided into 6 groups $(\mathrm{n}=10)$ according to the proposed irrigation methods:

Group 1 - Conventional irrigation - In this group, canals were irrigated with a 30 gauge Navitip needle (Ultradent, United States) coupled to a disposable syringe, positioned $2 \mathrm{~mm}$ below the working length. Three irrigations of 20 seconds were performed with $2.5 \%$ sodium hypochlorite followed by $17 \%$ EDTA and finally with $2.5 \%$ sodium hypochlorite again. In every 20 seconds of irrigation, $2 \mathrm{~mL}$ of the ir-rigation solution was used.

Group 2 - Passive Ultrasonic Irrigation (PUI) - In the passive ultrasonic irrigation group, the canal was filled with $2.5 \%$ sodium hypochlorite solution by using a 30-gauge Navitip needle, performing 3 agitations of 20 seconds. Thereafter, the same procedure was performed with 17\% EDTA and again with $2.5 \%$ sodium hypochlorite. In every 20 seconds of irrigation, $2 \mathrm{~mL}$ irrigation solution was used. For this procedure, an Irrisonic insert (Helse ind Ltda, Santa Rosa do Viterbo, São Paulo, Brazil) was positioned $2 \mathrm{~mm}$ from the working length and was used coupled to an NSK ultrasound at power 1.

Group 3 - Continuous Ultrasonic Irrigation (CUI) - In the continuous ultrasonic ir-rigation group, constant irrigation of 1 minute and $6 \mathrm{~mL}$ of $2.5 \%$ sodium hypochlorite was performed using a specific ultrasonic insert (Vista Dental Products). This was positioned $2 \mathrm{~mm}$ below the working length, coupled to an NSK ultra-sound unit at power 2 . The same procedure was repeated with the solution of $17 \%$ EDTA and $2.5 \%$ sodium hypochlorite.

Group 4 - Endoactivator - In the Endoactivator group (Dentsply; Maillefer, Ballaigues, Switzerland), the canal was filled with $2.5 \%$ sodium hypochlorite solution by using a 30 -gauge Navitip needle and 3 agitations of 20 seconds were per-formed. After this, the same procedure was performed with 17\% EDTA and with $2.5 \%$ sodium hypochlorite again. In every 20 second of irrigation and $2 \mathrm{~mL}$ irriga-tion solution was used. For this procedure, the specific polymer tip 25/04 was used, positioned $2 \mathrm{~mm}$ below of the working length. 
Group 5 - Easy Clean continuous rotation - In the group of Easy Clean in continuous rotation (Easy Dental Equipment, Belo Horizonte, MG, Brazil) the procedure was similar to that used in the previous group, however to promote the agitation of the irrigating solutions, a instrument Easy Clean 25/04 positioned $2 \mathrm{~mm}$ short of the working length was used, coupled to a contra-angle and driven with mi-cromotor at approximately 20.000 rotations per minute (KaVo Kerr Group, Char-lotte, NC, USA).

Group 6 - Easy Clean reciprocating movement - In the Easy Clean group in reciprocating motion (Easy Dental Equipment, Belo Horizonte, MG, Brazil), the pro-cedure was similar to that carried out in two previous groups, however, we used the Easy Clean instrument 25/04 coupled to the Easy motor (Easy dental equip-ment) in reciprocating motion, $2 \mathrm{~mm}$ short of the working length.

\section{Evaluation of the specimens}

After performing the irrigation protocols according to the groups, the teeth were submitted to the final scan (Figure 1D) using the same parameters as those of the initial scan. Each scan, both initial and final, resulted in images with TIF exten-sion, which were reconstructed using the program NRecon v1.6.4.8 (Bruker-microCT) and analyzed by the program CTan v1.11.10.0 (BrukermicroCT). Figu-re 2 shows representative micro-CT images of the teeth before and after the irri-gation protocols. Each sample was binarized, maintaining the proportions with a radiographic image, and then the volume (mm3) of debris in each lateral canal before and after the irrigation protocol were calculated. The percentage of debris removed from lateral canals in apical, middle and cervical thirds was then calcu-lated individually.

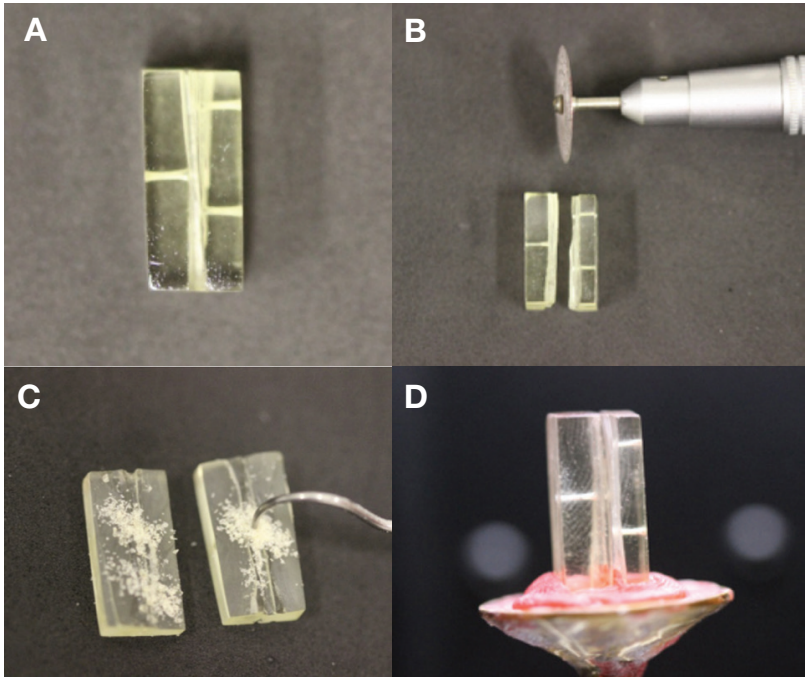

Figure 1 - (A) A sample made of acrylic that simulates maxillary incisor with lateral canals. (B) The teeth sectioned in buccolingual direction using a diamond disc coupled to a handpiece. (C) Bovine dentin debris being compressed into the lateral canals. (D) Specimen submitted to final scan after the irrigation protocols.

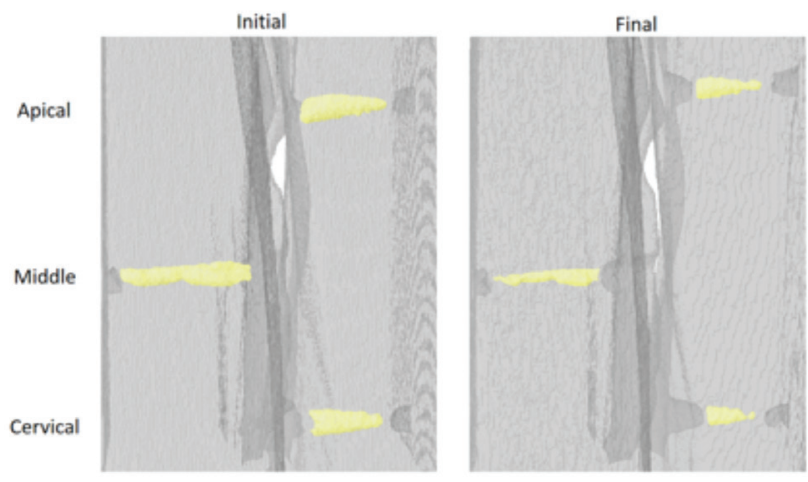

Figure 2 - Representative microCT images of the teeth before and after the irrigation proto-cols.

\section{Statistical analysis}

Data were submitted to the Shapiro-Wilks test to verify normality. Since normality was absent, Mann-Whitney test was used for intragroup analysis, Kruskal-Wallis and Dunn tests were used for the analysis of the groups. The level of significance was $5 \%$. 


\section{RESULTS}

Table I- Shows the median, minimum and maximum values of the volume $\left(\mathrm{mm}^{3}\right)$ of dentin debris in simulated lateral canals in the three thirds before and after of the irrigation protocols

\begin{tabular}{|c|c|c|c|c|c|c|}
\hline & \multicolumn{2}{|c|}{ Cervical } & \multicolumn{2}{|c|}{ Middle } & \multicolumn{2}{|c|}{ Apical } \\
\hline & Initial & Final & Initial & Final & Initial & Final \\
\hline Conventional & $\begin{array}{c}1^{A} \\
(0.69-1.82)\end{array}$ & $\begin{array}{c}0.92^{\mathrm{A}} \\
(0.5-1.56)\end{array}$ & $\begin{array}{c}1.09^{A} \\
(0.65-1.87)\end{array}$ & $\begin{array}{c}0.77^{\mathrm{B}} \\
(0.5-1.34)\end{array}$ & $\begin{array}{c}0.90^{A} \\
(0.68-1.9)\end{array}$ & $\begin{array}{c}0.74^{\mathrm{A}} \\
(0.42-1.44)\end{array}$ \\
\hline PUI & $\begin{array}{c}1.13^{A} \\
(0.76-1.54)\end{array}$ & $\begin{array}{c}0.27^{\mathrm{B}} \\
(0-0.75)\end{array}$ & $\begin{array}{c}1.30^{\AA} \\
(0.84-1.71)\end{array}$ & $\begin{array}{c}0.51^{\mathrm{B}} \\
(0-0.92)\end{array}$ & $\begin{array}{c}1.01^{A} \\
(0.74-1.51)\end{array}$ & $\begin{array}{c}0.59^{\mathrm{B}} \\
(0.42-1.02)\end{array}$ \\
\hline CUI & $\begin{array}{c}0.96^{A} \\
(0.68-1.49)\end{array}$ & $\begin{array}{c}0.8^{\mathrm{B}} \\
(0.53-1.35)\end{array}$ & $\begin{array}{c}1.43^{A} \\
(0.87-1.62)\end{array}$ & $\begin{array}{c}1.25^{A} \\
(0.87-1.55)\end{array}$ & $\begin{array}{c}0.94^{A} \\
(0.71-1.13)\end{array}$ & $\begin{array}{c}0.73^{B} \\
(0.52-1.13)\end{array}$ \\
\hline Endoactivator & $\begin{array}{c}1.29^{A} \\
(1.06-1.61)\end{array}$ & $\begin{array}{c}0.66^{\mathrm{B}} \\
(0.54-1.11)\end{array}$ & $\begin{array}{c}1.55^{A} \\
(0.94-2.70)\end{array}$ & $\begin{array}{c}1^{\mathrm{B}} \\
(0.58-1.43)\end{array}$ & $\begin{array}{c}1.13^{\mathrm{A}} \\
(0.81-1.28)\end{array}$ & $\begin{array}{c}0.65^{\mathrm{B}} \\
(0.51-0.87)\end{array}$ \\
\hline $\begin{array}{l}\text { Easy Clean } \\
\text { continuous }\end{array}$ & $\begin{array}{c}0.97^{\mathrm{A}} \\
(0.72-1.40)\end{array}$ & $\begin{array}{c}0.60^{B} \\
(0-0.93)\end{array}$ & $\begin{array}{c}1.14^{A} \\
(0.73-1.83)\end{array}$ & $\begin{array}{c}0.71^{\mathrm{B}} \\
(0.01-1.31)\end{array}$ & $\begin{array}{c}0.87^{A} \\
(0.77-1.03)\end{array}$ & $\begin{array}{c}0.60^{\mathrm{B}} \\
(0.44-0.77)\end{array}$ \\
\hline $\begin{array}{l}\text { Easy Clean } \\
\text { reciprocating }\end{array}$ & $\begin{array}{c}1.21^{A} \\
(1.08-1.95)\end{array}$ & $\begin{array}{c}1^{A} \\
(0.78-1.62)\end{array}$ & $\begin{array}{c}1.22^{A} \\
(0.35-1.59)\end{array}$ & $\begin{array}{c}1.01^{A} \\
(0.27-1.1)\end{array}$ & $\begin{array}{c}1.50^{A} \\
(1.1-1.98)\end{array}$ & $\begin{array}{c}0.99^{\mathrm{B}} \\
(0.68-1.37)\end{array}$ \\
\hline
\end{tabular}

Different letters indicate significant differences in the amount of initial debris and after the irrigation protocols ( $\mathrm{p}$ « 0.05$)$.

There were significant differences between the value of initial volume of debris and the final after the use of irrigation protocols $(\mathrm{p}<0.05)$; except for the conventional irrigation group in the apical and cervical thirds, Easy Clean reciprocating group in the middle and cervical thirds, and CUI group in the middle third ( $\mathrm{p}>0.05)$.

Table II - Presents the median, minimum and maximum values of the percentage of debris removal in the three-thirds analyzed provided by different irrigation methods test-ed

\begin{tabular}{|cccc|}
\hline & Cervical & Middle & Apical \\
\hline Initial & Initial & Initial \\
\hline Conventional & $16.4(0-31.6)^{\mathrm{Aa}}$ & $27.8(20.3-31.9)^{\mathrm{ACa}}$ & $25.5(0-40.7)^{\mathrm{ABa}}$ \\
\hline PUI & $72.1(45.7-99.2)^{\mathrm{Cb}}$ & $57.6(33-99.9)^{\mathrm{Bb}}$ & $42.5(25.9-52.1)^{\mathrm{Ba}}$ \\
\hline CUI & $17.9(0-61.9)^{\mathrm{Aba}}$ & $5.15(0-15.8)^{\mathrm{Cb}}$ & $19.3(0-32.8)^{\mathrm{Aa}}$ \\
\hline $\begin{array}{c}\text { Endoactivator } \\
\text { Easy Clean } \\
\text { continuous }\end{array}$ & $46(31.2-53.5)^{\mathrm{BCa}}$ & $37.6(23.6-52.4)^{\mathrm{ABa}}$ & $43.5(22.4-49.8)^{\mathrm{Ba}}$ \\
\hline $\begin{array}{c}\text { Easy Clean } \\
\text { reciprocating }\end{array}$ & $16.4(8.8-99.99 .9)^{\mathrm{ABCa}}$ & $30.6(20.3-99.5)^{\mathrm{ABa}}$ & $29.1(20.4-49.6)^{\mathrm{ABa}}$ \\
\hline
\end{tabular}

Different upper-case letters indicate significant differences between irrigation methods in each third ( $p$ « 0.05). Different lowercase letters indicate significant differences between thirds in each irrigation method. $(p<0.05)$. $\mathrm{n}$ the apical third, Endoactivator and PUI groups were the methods that provided a higher percentage of debris removal from lateral canals. In the middle third, PUI group showed the highest percentage of removal that differed statistically from conventional irrigation, Easy Clean reciprocating and CUI groups $(\mathrm{p}<0.05)$. Endoacti-vator and Easy Clean in continuous rotation groups also presented higher debris removal values than CUI group in the middle third ( $p<0.05)$. For the cervical third, the highest percentage of debris removal occurred in PUI group, that was statistical-ly more efficient than conventional irrigation, Easy Clean reciprocating and CUI groups. As well, Endoactivator group favored removal values than those of the conventional irrigation group significantly $(\mathrm{p}<0.05)$. In other comparisons there were no significant differences ( $p>0.05$ ).

Comparing the thirds of the same group, there were significant differences for Easy Clean reciprocating, in which presented a significantly higher removal value in the apical third compared with the cervical third; PUI group showed significantly higher removal values in the middle and cervical thirds in comparison with the apical 
and CUI Group, in which the removal value was significantly lower in the middle third in comparison with apical and cervical levels ( $\mathrm{p}$ $<0.05$ ). For the other groups, there were no statistically significant differences $(p>0.05)$.

\section{DISCUSSION}

This in vitro study evaluated the cleaning of dentin debris from simulated lateral canals provided by different methods of irrigation agitation (conventional, PUI, CUI, EndoActivator, Easy Clean continuous rotation and Easy Clean in recipro-cating motion). According to the results, the null hypothesis was rejected since there were statistical differences between the irrigation methods tested.

In this current methodology, acrylic teeth were used in conjunction with computerized microtomography (micro-CT), which has already been used in different stu-dies for different types of analysis [18- 20]. Besides, using bovine dentin debris in artificial grooves was used in other studies $[21,22]$ to simulate smear layer pro-moted by the instrumentation. These acrylic teeth were chosen because it was possible to standardize the diameter of the lateral canals and their location in the tooth, which could be compared by levels (apical, middle and cervical). The use of acrylic teeth allows analysis employing micro-CT, thus enabling volumetric analysis of the debris inside the lateral canals before and after the irrigation pro-tocol, as this methodology does not require destruction of the sample. Also, this type of analysis provides less subjective results, because it is a quantitative anal-ysis and therefore more reliable. In addition, the initial scanning of the teeth by micro-CT allowed the groups to be paired as regards the initial volume of debris in lateral canals.

As in the present results, other studies have shown that conventional irrigation has certain limitations relative to disinfection and removal of dentin debris, especially in the apical third and complex areas such as lateral canals $[16,17,23,24]$. Therefore, using a method of agitating the irrigating solution is necessary in order to potentiate it and to obtain a better cleaning of the main canal, particularly the apical third, and the areas that are difficult to access such as lateral canals $[4,16,17,25]$.

In the analysis between groups, the results of this study showed that irrespective of the third analyzed, PUI obtained the highest percentages of dentin debris re-moval from the lateral canals in comparison with CUI $(\mathrm{p}<0.05)$. Although there are no published articles comparing the two systems with respect to removing debris from lateral canals, a previous study by Castelo-Baz [25] reported that CUI was capable of enabling greater penetration of irrigating solution into simulated lateral canals than PUI. However, this previous study verified the penetration of the solution and not the cleaning promoted in these regions; moreover, no volu-metric analysis was performed. The differences may also be related to other aspects of the methodology that was different.

In the middle and cervical thirds, PUI also demonstrated greater effectiveness than conventional irrigation and Easy Clean reciprocating. Relative to the greater effectiveness of PUI in comparison with conventional irrigation, the results of this study corroborated the findings of several previous studies that analyzed the re-moval of debris in complex anatomic areas $[4,16,25,26]$. As regards Easy Clean in reciprocating motion (ECR), there is still no consensus in the literature when it was compared with PUI, since no difference between them has been shown in the cleaning of debris from the isthmus [16]. However, Kato et al. reported that ECR was better than PUI in the removal of smear layer in the apical third of the canal, but these previous studies could not be compared with the present study because in the previous one, the removal of debris from lateral canals was not analyzed [17].

The results also showed that the Endoactivator was more capable of removing debris from the lateral canals than CUI in the apical and middle thirds; and the Easy Clean was shown to be more effective than CUI, but 
only in the middle third $(\mathrm{p}<0.05)$. There are no studies in the literature comparing these methods so that the results obtained can be cross-checked.

PUI, Endoactivator and Easy Clean in continuous rotation showed no significant differences between them ( $p>0.05$ ). Although there are no studies with the same type of analysis in the literature, these results corroborate the findings of other studies in which there was no difference between the PUI and the Endoactivator in the ability to deliver $[26,27]$. This probably occurred because of the ability of these three methods to promote intensely turbulence of the irrigating solution to the point of penetrating into the lateral canals and removing dentin debris.

In the comparison between the thirds of the same group, there were significant differences for the Easy Clean reciprocating group, in which there was a significantly higher removal value in the apical third in comparison with the cervical third; in the PUI method, in which the removal value was significantly higher in the middle and cervical thirds in comparison with the apical third. For the CUI method the removal value was significantly lower in the middle third in compari-son with the apical and cervical thirds.

\section{ACKNOWLEDGMENTS}

This work was supported by grants from The São Paulo Research Foundation - FAPESP.

\section{REFERENCES}

1. Siqueira JF Jr, Rôças IN. Clinical implications and microbiology of bacterial persistence after treatment procedures. J Endod. 2008 Nov;34(11):1291-301.e3. doi:10.1016/j.joen.2008.07.028. Epub 2008 Sep 17.

2. Gutarts R, Nusstein J, Reader A,Beck M. In vivo debridement efficacy of ultrasonicirrigation following hand-rotary instrumentation in human mandibular mo-lars. J Endod. 2005 Mar;31(3):166-70.

3. GuLS, Kim JR, Ling J, Choi KK, Pashley DH, Tay FR. Review of contemporary irrigant agitation techniques and devices. JEndod. 2009 Jun;35(6):791-804 . doi:10.1016/j.joen.2009.03.010.

4. de Gregorio C,EstevezR, CisnerosR, Paranjpe A, Cohenca N. Efficacy of different irrigation and activation systems on the penetration of sodium hypochlorite into simulated lateral canals and up to working length: an in vitro study.J Endod. 2010 Jul:36(7):1216-21. doi:10.1016/j.joen.2010.02.019. Epub2010Mar 29.
5. Burleson A, Nusstein J, Reader A, Beck M. The in vivo evaluation of Hand/ Rotatory/Ultrasound instrumentation in necrotic, human mandibular mo-lars. JEndod. 2007 Jul:33(7):782-7.

6. Siqueira JF Jr, Lima KC, Magalhaes FA, Lopes HP, de Uzeda M. Mechanical reduction of the bacterial population in the root canal by three instrumentation techniques. J Endod. 1999 May;25(5):332-5.

7. Peters $0 \mathrm{~A}$. Current challenges and concepts in the preparation of root canal sys-tems: areview. JEndod. 2004 Aug;30(8):559-67.

8. PaquéF,Laib A, Gautschi H,Zehnder M. Hard-tissue debris accumulation analy-sis by high-resolution computed tomography scans. J Endod. 2009 Jul;35(7):1044-7. doi: 10.1016/j.joen.2009.04.026.

9. De-Deus G, Marins J, Neves Ade A, Reis C,Fidel S, Versiani MA, etal. Assessing accumulated hard-tissue debris using micro-computed tomography and free software for image processing and analysis. J Endod. 2014 Feb;40(2):271-6. doi: 10.1016/.joen.2013.07.025. Epub 2013 Sep 11.

10. De-Deus G,Murad C,Paciornik S, Reis CM, Coutinho-Filho T. The effect of the canal-filled area on the bacterial leakage of oval-shaped canals. Int Endod J. 2008 Mar;41(3):183-90. Epub2007 Nov1.

11. Nielsen BA, Baumgartner JC. Comparison of the endovac system to needle irrigation of root canals. J Endod. 2007 May;33(5):611-5. Epub 2007 Mar 26.

12. Caron G,Nham K, Bronnec F,Machtou P.Effectiveness of different final irri-gant activation protocols on smear layer removal in curved canals. J Endod. 2010 Aug;36(8):1361-6. doi: 10.1016/j.joen.2010.03.037.Epub 2010 May 13.

13. Versiani MA,De-Deus G, Vera J, SouzaE, Steier L, Pécora JD, etal.3D mapping of the irrigated areas of the root canal space using micro-computed tomography. Clin Oral Investig. 2015 May;19(4):859-66. doi: 10.1007/s0078414-1311-5. Epub 2014 Sep 4.

14. Jiang LM, Verhaagen B, Versluis M, van der Sluis LW. Influence of the oscillation direction of an ultrasonic file on the cleaning efficacy of passive ultrasonic irrigation. JEndod. 2010 Aug;36(8):1372-6. doi:10.1016/j. joen.2010.03.019. Epub2010 May 13.

15. Van Der Sluis LW, Vogels MP, Verhaagen B, Macedo R, Wesselink PR. Study on the influence of refreshment/activation cycles and irrigants on mechani-cal cleaning efficiency during ultrasonic activation of the irrigant. JEndod. 2010 Apr;36(4):737-40. doi: 10.1016/j.joen.2009.12.004. Epub 2010Feb 6.

16. Duque JA, Duarte MA, Canali LC,ZancanRF, Vivan RR,Bernardes RA, etal. Comparative Effectiveness of New Mechanical Irrigant Agitating Devices for Debris Removal from the Canal and Isthmus of Mesial Roots of Mandibular Molars. JEndod. 2017 Feb;43(2):326-331. doi:10.1016/j.joen.2016.10.009. Epub 2016 Dec 15.

17. Kato AS, Cunha RS, da Silveira Bueno CE, Pelegrine RA, FontanaCE, de Martin AS. Investigation of the Efficacy of Passive Ultrasonic Irrigation Versus Irrigation with Reciprocating Activation: An Environmental Scanning Electron Microscopic Study.J Endod. 2016 Apr;42(4):659-63. doi:10.1016/j. joen.2016.01.016. Epub2016 Feb20.

18. Lee SJ, Wu MK, Wesselink PR. The efficacy of ultrasonic irrigation to remove artificially placed dentine debris from different-sized simulated plastic root canals. Int Endod J.2004 Sep;37(9):607-12.

19. Duarte MA, Balan NV,Zeferino MA, Vivan RR, Morais CA, Tanomaru-Filho M, et al. Effect of ultrasonic activation on $\mathrm{pH}$ and calcium released by calcium hydroxide pastes in simulated external root resorption. JEndod. 2012 Jun;38(6):834-7. doi: 10.1016/j.joen.2012.03.005. Epub 2012 Apr 24

20. Cavenago BC,Pereira TC,Duarte MA, Ordinola-Zapata R,Marciano MA, Bramante CM, Bernardineli N. Influence of powder-to-water ratio on radiopacity, setting time, $\mathrm{pH}$, calcium ion release and a micro-CT volumetric solubility of white mineral trioxide aggregate. Int Endod J.2014 Feb;47(2):120-6. doi: 10.1111/iej.12120. Epub 2013 May 3. 
21. Cesario F, Hungaro Duarte MA, Duque JA, Alcalde MP,de Andrade FB, Reis So MV, et al. Comparisons by microcomputed tomography of the efficiency of different irrigation techniques for removing dentinal debris fromartificial grooves. JConserv Dent 2018_Jul-Aug;21(4):383-387.doi:10.4103/JCD.JCD_286_16.

22. Martins Justo A, Abreu da Rosa R, Santini MF,Cardoso Ferreira MB,Pereira JR, Húngaro Duarte MA, etal. Effectiveness of final irrigant protocols for debris removal from simulated canal irregularities. J Endod. 2014 Dec;40(12):2009-14.

23. Adcock JM, Sidow SJ, Looney SW, Liu Y,McNally K, Lindsey K, Tay FR. Histologic evaluation of canal and isthmus debridement efficacies of two different ir-rigant delivery techniques in a closed system. J Endod. 2011 Apr;37(4):544-8. doi:10.1016/j.joen.2011.01.006.

24. Mozo S, LlenaC, Chieffi N, Forner L, Ferrari M. Effectiveness of passive ultrasonic irrigation in improving elimination of smear layer and opening dentinal tubules. J Clin Exp Dent. 2014 Feb 1;6(1):e47-52. doi: 10.4317/jced.51297. eCol-lection2014 Feb.
25. Castelo-BazP,Martín-Biedma B, Cantatore G, Ruíz-Piñón M,Bahillo J, Ri-vasMundiña B, et al. In vitro comparison of passive and continuous ultrasonic ir-rigation in simulated lateral canals of extracted teeth. J Endod. 2012 May;38(5):688-91. doi:10.1016/j.joen.2011.12.032. Epub 2012 Jan 29.

26. de Gregorio C, Estevez R, Cisneros R, Heilborn C, Cohenca N. Effect of EDTA, sonic, and ultrasonic activation on the penetration of sodium hypochlorite into simulated lateral canals: an in vitro study. J Endod. 2009 Jun;35(6):891-5. doi: 10.1016/j.joen.2009.03.015.

27. Andrade-Junior CV, Batista RM, Marceliano-Alves M, Alves FRF, SilvaEJNL Efficacy of a new activation device in irrigant penetration into simulated lateral canals. Eur Endod J.2016 0ct; 1:-1-5.

\section{Pedro Cesar Gomes Titato}

\section{(Corresponding address)}

Bauru School of Dentistry, University of São Paulo, Operative

Dentistry, Endodon-tics and Dental Materials

Bauru, São Paulo, BR

Address: Padre João, 14-57. Bauru/São Paulo - Brazil

Date submitted: 2018 Aug 08

pedro.titato@usp.br 